\title{
UPAYA MENINGKATKAN INTERAKSI SOSIAL PESERTA DIDIK DENGAN PENGGUNAAN METODE GROUP INVATIGATION
}

\author{
Rizqi Dwi Susetyaning Yuniar, Esa Nursafitri, Tatu Fitri Zulfiah \\ rizqidwi1906@gmail.com \\ Mahasiswa Fakultas Agama Islam Universitas Ibn Khaldun
}

\begin{abstract}
ABSTRAK
Group investigation adalah model atau metode pembelajaran Kooperative yang di kembangkan oleh Sholomo dan Sharon di Universitas Tel Aviv (Slavin, 1995). Yang mana model pembelajaran ini ialah menempatkan peserta didik terbagi menjadi beberapa kelompok untuk dapat menyelesaikan problematika atau fenomena yang ada. Tujuan penelitian Untuk menganalisis interaksi sosial peserta didik, keefektifan penggunaan metode group invatigation dan Untuk menentukan pengaruh antara penggunaan metode group invatigation dengan interaksi sosial peserta didik. Metode penelitian ini memuat: Metode penelitian, Variabel yang diselidiki dan Prosedur penelitian. Hasil dari penelitian ini dapat digunakan oleh pendidik sebagai pedoman untuk meningkatkan interaksi sosial peserta didik serta untuk meningkatkan kualitas pembelajaran dengan menggunakan metode pembelajaran kooperatif.
\end{abstract}

\section{Kata Kunci: Interaksi Sosial, Metode Group Invatigation, Pembelajaran.}

\section{PENDAHULUAN}

\section{Latar Belakang}

Pada saat ini telah banyak di temukan metode-metode pembelajaran yang sangat beragam jenis dan tujuannya, salah satunya ialah metode pembelajaran kooperatife. Metode pembelajaran kooperatife pun banyak jenisnya, seperti metode jigsaw, Team Game Tournament (TGT), Cooperative Integrated Reading and Compotition (CIRC), Student Team Achivement Division (STAD), DAN Team Assisted Individualization (TAI), dan salah satunya adalah Group Invastigation (GI).

Group investigation adalah model atau metode pembelajaran Kooperative yang di kembangkan oleh Sholomo dan Sharon di Universitas Tel Aviv (Slavin, 1995). Yang mana model pembelajaran ini ialah menempatkan peserta didik terbagi menjadi beberapa kelompok untuk dapat menyelesaikan problematika atau fenomena yang ada. Oleh karena itu di perlukan interaksi sosial yang baik diantara peserta didik yang satu dengan yang lainnya.

Dalam penggunaan model atau metode seperti ini, siswa akan di hadapkan dengan beberapa peserta didik lain yang akan bersama-sama dengannya memecahkan suatu masasalah. Oleh karena itu sangat di perlukan interaksi yang baik antara peserta didik yang satu dengan yang lainnya. Jika peserta didik dapat berinteraksi dengan baik terhadap anggota kelompoknya, maka ia pasti akan mendapatkan kenyamanan pula kesenangan dalam mengerjakan tugas yang di kerjakan. Tetapi sebaliknya, jika ia tidak mampu berinteraksi dengan baik terhadap anggota kelompoknya maka boleh jadi ia 
akan merasa di asingkan atau merasa tidak di butuhkan sumbangsih pikirannya dalam proses pemecahan masalah tersebut.

Dengan berkembang pesatnya teknologi saat ini, sudah pasti banyak manfaat yang bisa di dapati karena nya, terutama dalam bidang pendidikan. Dengan teknologi pendidik mampu menghadirkan galaksi yang ada di langit ke dalam kelas, menghadirkan indahnya terumbu karang ke dalam kelas, melihat aneka ragam budaya indonesia yang berada di pelosok-pelosok, menghadirkan peristiwa yang kejadiannya tidak mungkin bisa di ulang kembali, dan masih banyak lainnya. Hal-halnya yang dulu sangat tidak mungkin atau sulit untuk di wujudkan, pada saat ini hanya dengan teknologi semua bisa terwujud. Dengan begitu tujuan pendidikan yang di rumuskan dalam undang-undang atau tujuan yang di rumuskan oleh pendidik itu sendiri akan mudah terrealisasikan atau dapat tercapai. Sehingga banyak ilmuan pendidikan yang terus mencari manfaat yang bisa di ambil dari teknologi untu kemajuan dunia pendidikan.

Di samping dampak positif yang kita dapatkan, tentu pula ada dampak negative yang kita harus terima. Salah satunya, dengan kemajuan teknologi saat ini salah satunya yaitu gadget, menyababkan peserta didik menjadi sosok yang individualisme. Sehingga timbulah peserta didik yang kurang peka terhadap lingkungan sekitar.

Oleh sebab itu penulis tertarik untuk melakukan penelitian peningkatan interaksi sosial peserta didik dengan menggunakan model atau metode pembelajaran Group Investigation. Yang mana pada model atau metode pembelajaran ini siswa di bagi menjadi beberapa kelompok, yang kemudian akan di lihat sejauh mana ia bisa berinteraksi, berkomunikasi dan bekerja sama dengan baik demi terpecahkannya masalah yang di hadapi.

\section{Rumusan Masalah}

1. Bagaimana interaksi sosial peserta didik di SMK Ibnu Aqil Bogor?

2. Bagaimana keefektifan penggunaan metode pembelajaran Group Invatigation di SMK Ibnu Aqil Bogor?

3. Bagaimana pengaruh penerapan metode Group Invatigation terhadap interaksi sosial peserta didik di SMK Ibnu Aqil Bogor?

\section{Tujuan Penelitian}

1. Untuk menganalisis interaksi sosial peserta didik di SMK Ibnu Aqil Bogor

2. Untuk menganalisis keefektifan penggunaan metode group invatigation di SMK Ibnu Aqil Bogor

3. Untuk menentukan pengaruh antara penggunaan metode group invatigation dengan interaksi sosial peserta didik di SMK Ibnu Aqil Bogor

\section{Urgensi Penelitian}

Urgensi dari penelitian ini yaitu mengurangi sifat individual peserta didik di SMK sehingga mereka dapat memiliki kemampuan interaksi sosial yang baik.

\section{Manfaat Penelitian}

1. Hasil penelitian ini dapat di gunakan oleh sekolah sebagai bahan pertimbangan atau bahan acuan untuk meningkatkan interaksi sosial peserta didik di lingkungan sekolah maupun lingkungan masyarakat.

2. Hasil penelitian ini dapat digunakan juga oleh Universitas sebagai bahan masukan untuk meningkatkan kualitas lulusan yang tidak hanya mempuni dalam bidang akademik nya saja 
melainkan pula dalam segala bidang, salah satunya bidang sosial.

\section{TINJAUAN PUSTAKA}

\section{Interaksi sosial}

Pengertian Interaksi Sosial merupakan hubungan-hubungan sosial yang dinamis yang menyangkut hubungan antara orang-orang perorangan, antara kelompok-kelompok manusia, maupun antara orang perorangan dengan kelompok manusia. Apabila dua orang bertemu, interaksi sosial dimulai pada saat itu, mereka saling menegur, berjabat tangan, saling berbicara ataupun saling berkelahi. Aktivitas-aktivitas semacam itu merupakan bentuk-bentuk interaksi sosial. Walaupun orang-orang yang bertemu muka tersebut tidak saling bicara, tidak saling menukar tanda-tanda, interaksi sosial telah terjadi karena masing-masing sadar akan adanya pihak yang lain yang menyebabkan perubahan-perubahan dalam perasaan maupun syaraf orang-orang yang bersangkutan, yang disebabkan oleh misalnyabau keringat, minyak wangi, suara berjalan dan sebagainya.

Proses hubungan tersebut berupa antar aksi sosialyang terjadi dalam kehidupan sehari-hari secara terusmenerus. Antar aksi (interaksi sosial), dimaksudkan sebagai pengaruh timbal balik antara dua belah pihak, yaitu antara individu atau kelompok lainnya dalam rangka mencapai tujuan yang tertentu. Proses sosial pada dasarnya merupakan siklus perkembangan dari struktur sosial yang merupakan aspek dinamis dalam kehidupan bermasyarakat. Mengenai interaksi sosial sendiri dapat diartikan sebagai hubungan-hubungan sosial timbal balikyang dinamis, yang menyangkut hubungan antara orang-orang secara perorangan, antara kelompok-kelompok manusia, maupun antara orang dengan kelompok- kelompok manusia. Menurut Roucek dan Warren, interaksi adalah satu proses, melalui tindak balas tiap-tiap kelompok berurut-urut menjadi unsur penggerak bagi tindak balas dari kelompok lain. Ia adalah suatu proses timbal balik, dengan nama satu kelompok dipengaruhi tingkah lakukretif pihak lain dan dengan berbuat dengan demikian ia mempengaruhi tingkah laku orang lain.

Interaksi sosial merupakan faktor utama dalam kehidupan sosial. Interaksi sosial merupakan hubungan sosial yang dinamis yang menyangkut hubungan timbal balik antar individu, antar kelompok manusia, maupun antar orang dengan sekelompok manusia. Bentuk interaksi sosial adalah akomodasi, kerja sama, persaingan dan pertikaian.

Apabila dua orang atau lebih bertemu akan terjadi interaksi sosial. Interaksi soisal tersebut bisa dalam situasi persahabatan maupun permusuhan, bisa dengan tutur kata, jabat tangan bahasa isyarat atau tanpa kontak fisik. Bahkan hanya dengan bau keringat sudah terjadi interaksi sosial karena telah mengubah perasaan atau saraf orang bersangkutan untuk menentukan tindakan. Interaksi sosial hanya dapat berlangsung antara pihak-pihak apabila terjadi reaksi dari kedua belah pihak. Interaksi sosial tidak mungkin terjadi apabila manusia mengadakan hubungan yang berlangsung dengan sesuatu yang sama sekali tidak berpengaruh terhadap sistem syarafnya sebagai akibat hubungan yang di maksud. 
Interaksi sosial antara kelompokkelompok manusia terjadi antara kelompok tersebut sebagai kesatuandan bisanya tidak menyangkut pribadi-pribadi anggotaanggotanya. Suatu contoh dapat dikemukakan dari perang kedua yang lalu sebagaimana dilukiskan oleh Gillin dan Gillin. Pada tanggal 7 desember 1939, patroli Prancis telah berhasil menawan tiga orang pajurit Jerman. Salah seorang tawanan menderita luka-luka pada tangannya sewaktu terjadi pertempuran. Para tawanan dibawa ke garis belakang. Ditempat yang aga? terang, tawanan yang luka-luka dan prajutit Prancis yang telah menembaknya saling mengenal dan saling memeluk. Ternyata sebelum perang keduanya adalah sahabat yang selalu bersaing pada setiap perlombaan balap sepeda bayaran. Mereka bukan musuh secara pribadi, tetapi kelompoknya masing-masing (yaitu negara jerman dan prancis yang bermusuahan. Interaksi sosial anatara kelompok2 sosial tersebut tidak bersifat pribadi.

\section{Ciri-ciri interaksi sosial}

Dalam buku ilmu Sosial dan Budaya karangan Herimanto dan Winarno, ciri-ciri interaksi sosial sebagai berikut:

1. Pelakunya lebih dari satu orang.

2. Adanya komunikasi antar pelaku melalui kontak sosial

3. Mempunyai maksud dan tujuan, terlepas dari sama atau tidaknya tujuan tersebut dengan yang diperkirakan pelaku.

4. Ada dimensi waktu yang akan ditentukan sikap aksi yang sedang berlangsung.

\section{Jenis-jenis Interaksi Sosial}

Interaksi sosial dibagi menjadi tiga jenis, yaitu :

1. Interaksi antara individu dan individu. pada saat dua individu bertemu, interaksi sosial sudah mulai terjadi. Walaupun kedua individu itu tidak melakukan kegiatan apa-apa, namun sebenarnya interaksi sosial telah terjadi apabila masing-masing pihak sadar akan adanya pihak lain yang menyebabkan perubahan dalam diri masing-masing.

2. Interaksi antara kelompok dan kelompok. Interaksi jenis ini terjadi pada kelompok sebagai satu kesatuan bukan sebagai pribadi-pribadi anggota kelompok yang bersangkitan .

3. Interaksi antara individu dan kelompok. Bentuk interaksi disini berbeda-beda sesuai dengan keadaan. Interaksi tersebut lebih mencolok manakala terjadi pembenturan antara kepentingan perorangan dan kepentingan kelompok.

\section{Syarat-syarat Interaksi Sosial}

Terjadinya interaksi sosial karena adanya saling mengerti tentang maksud dan tujua masing-masing pihak dalam suatu hubungan sosial. Orang mempengaruhi tingkah laku orang lain melalui kontak. Kontak ini mungkin berlangsung melalui organisme fisik, seperti dalam obrolan, pendengaran, melakukan gerakan pada beberapa bagian bdan, melihat dan lain-lain lagi, atau secara tindak langsung melalui tulisan atau dengan berhubungan dari jauh.

Dalam proses sosial, baru dapat dikatakan terjadi interaksi sosial apabila telah memenunhi persyaratan sebagai aspek kehidupan bersama, yaitu adanya kontak sosial dan komunikasi sosial. 


\section{Kontak sosial}

Kontak sosial adalah hubungan antara satu orang atau lebih, melalui percakapan dengan saling mengerti tentang maksud dan tujuan masing-masing dalam kehidupan masyarakat. Kontak sosial dapat terjadi secara langsung ataupun tidak langsung antara satu pihak dengan pihak lainnya. Kontak sosial tidak langsung adalah kontak sosial yang menggunakan alat, sebagai perantara; misalnya; melalui telepon, radio, surat dan lain-lain sedangkan kontak sosial secara langsung adalah kontak sosial melalui suatu pertemuan dengan bertatap muka dan berdialog diantara dua belah pihak tersebut.

2. Komunikasi sosial

Komunikasi sosial adalah syarat pokok lain dari pada proses sosial. Komunikasi sosial mengandung pengertian persamaan pandangan antaraorang-orang yang berinteraksi terhadap sesuatu. Menurut Soerjono Soekanto, konumikasi adalah bahwa seseorang memberikan tafsiran pada peri kelakuan orang lain (yang berwujud pembicaraan, gerak-gerak badaniyah atau sikap) perasaan-perasaan apa yang ingin disampaikan oleh orang tersebut. dengan adanya komunikasi, maka sikap dan perasaan disatu pihak orang atau sekelompok orang dapat diketahui dan dipahami oleh pihak orang atau sekelompok orang lain.

\section{Bentuk-bentuk Interaksi Sosial}

Bentuk-bentuk interaksi sosial dapat berupa kerja sama (cooperative), persaingan (competition), bahkan dapat juga berbentuk pertentangan (conflict), dan akomodasi (accomodation). Keempat bentuk dari interaksi sosial tersebut tidak perlu merupakan suatu kontinuitas, didalam arti bahwa interaksi itu dimulai dengan kerja sama yang kemudian menjadi persaingan serta memuncak menjadi pertikaian akhirnya sampai pada akomodasi. Akan tetapi ada baiknya untuk menelaah proses-proses interaksi tersebut didalam kelangsungannya. Adapun bentukbentunya sebagai berikut:

\section{Kerja sama ( cooperation)}

Beberapa sosiolog menganggap bahwa kerja sama merupakan bentuk interaksi sosial yang pokok. Kerja sama timbul karena orientasi orang-perorangan terhadap kelompoknya (yaitu in-group-nya) dan kelompok lainnya ( yang merupakan outgroup-nya). Betapa pentingnya fungsi kerja sama,digambarkan oleh Charles H. Cooley sebagai berikut : "Kerja sama timbul apabila orang menyadari bahwa mereka mempunyaikepentingan-kepentingan yang sama dan pada saat yang bersamaan mempunyai banyak cukup pengetahuan dan pengendalian terhadap diri sendiri untuk memenuhi kepentingan-kepentingan tersebut;kesadaran akan adanya kepentingan-kepentinganyang sama dan adanya organisasi merupakan fakta-fakta yang penting dalam kerja sama yang berguna.

\section{Akomodasi}

Akomodasi yang menunjuk pada suatu keadaan,berarti adanya suatu keseimbangan dalam interaksi antara orang-perorangan atau kelompokkelompok manusia dalam kaitannya dalam norma-norma sosialdan nilai-nilai sosial yang berlaku di dalam masyarakat.

Menurut Gillin dan Gillin, akomodasi adalah suatau pengertian yang digunakan oleh para sosiolog untuk menggambarkan suatu proses dalam hubungan-hubungan sosial yang sama artinyadengan pengertian adaptasi yang digunakan oleh ahli-ahli biologi untuk menunjuk pada suatu proses dimana makhluk - makhluk hidup 
menyesuaikan dirinya dengan alam sekitarnya.

\section{Persaingan}

Persaingan dapat diartikan sebagai suatu proses sosial,individuatau kelompokkelompok manusia yang bersaing mencari keuntungan melalui bidang-bidang kehidupan yang pada suatu masa tertentu menjadi pusat perhatian umum (baik perseorangan maupun kelompok manusia) dengan cara menarik perhatian publik atau dengan mempertajam prasangka yang telah ada tanpa mempergunakan ancaman atau kekerasan. Persaingan mempunyai dua tipe umum,yakni yang bersifat pribadi dan tidak pribadi. Persaingan yang bersifat pribadi, orang-perorangan, atau individu secara langsung misalnya memperoleh kedudukan tertentu didalam suatu organisasi.

\section{Pertentangan}

Pribadi maupun kelompok menyadari adanya perbedaan-perbedaan misalnya dalam ciri-ciri badaniah,emosi,unsurunsurkebudayaan,pola-pola perilaku,dan seterusnya dengan pihak lain. Ciri tersebut dapat mempertajam perbedaan yang ada hingga menjadi suatu suatu pertentangan atau pertikaian. Pertentangan atau pertikaian merupaka suatu proses sosial dimana individu atau kelompok berusaha untuk memenuhi tujuannya dengan jalan menantang pihak lawan yang disertai dengan ancaman dan/atau kekerasan.

\section{Metode Group Investigation}

Strategi belajar kooperatif Group Investigation dikembangkan oleh Shlomo dan Sharan dan Yeal Sharan di Universitas Tel Aviv, Israel. Belajar kooperatif dengan teknik Group Investigation sangat cocok untuk bidang kajian yang memerlukan kegiatan studi proyek terintegrasi (Slavin, 1995) yang mengarah pada kegiatan perolehan, analisis, dan sintesis informasi dalam upaya untuk memecahkan suatu masalah. Oleh karenanya kesuksesan implementasi teknik kooperatif Group Investigation sangat tergantung dari pelatihan awal dalam penguasaan keterampilan komunikasi dan sosial.

Group Investigasion tidak akan dapat diimplementasikan dalam lingkungan pendidikan yang tidak mendukung dialog interpersonal atau yang tidak memperhatikan dimensi rasa sosial dari pembelajaran didalam kelas. Komunikasi dan interaksi kooperatif di antara sesama teman sekelas akan mencapai hasil terbaik apabila dilakukan dalam kelompok kecil, dimana pertukaran diantara teman sekelas dan sikap-sikap kooperatif bisa terus bertahan.

Group Investigation menempatkan siswa bersama dalam tiga sampai enam kelompok untuk menyelidiki atau menyelesaikan beberapa masalah umum (Tan, Sharan, dan Lee, 2007). Contohcontohnya dapat mencakup eksperimentasi studi-studi sains dan sosial, proyek home economics, atau penciptaan diorama atau kolase dalam seni.

Menurut Sharan dan Sharan (Sharan, 2009:1440) karakteristik unik investigasi kelompok ada pada integrasi dari empat fitur dasar yaitu investigasi, interaksi, penafsiran, dan motivasi intrinsik. Lebih lanjut Sharan (2009:145) menguraikan masing-masing sebagai berikut:

\section{Investigasi}

Investigasi dimulai ketika guru memberikan masalah yang menantang dan rumit kepada kelas. Ditengah-tengah berlangsungnya penelitian mereka untuk mencari jawaban masalah siswa membangun pengetahuan yang mereka peroleh. Proses investigasi menekankan inisiatif siswa dibuktikan dengan 
pertanyaan-pertanyaan yang mereka ajukan, dengan sumber-sumber yang mereka temukan, dan jawaban yang mereka rumuskan. Siswa mencari informasi dan gagasan dengan bekerjasama dengan rekan mereka dan menggabungkannya bersama pendapat informasi, gagasan, ketertarikan, dan pengalaman yang masing-masing mereka bawa ketika mengerjakan tugas.

\section{Interaksi}

Intekasi diantara siswa penting bagi investigasi kelompok. Ini adalah kendaraan yang dengannya siswa saling memberikan dorongan, saling mengembangkan gagasan satu sama lain, saling membantu untuk memfokuskan perhatian mereka terhadap tugas, dan bahkan saling mempertentangkan gagasan dengan menggunakan sudut pandang yang bersebrangan. Menurut Thelen, 1981 (dalam Sharan, 2009:147) bahwa interaksi sosial dan intelektual merupakan cara yang digunakan siswa untuk mengolah lagi pengetahuan personal mereka dihadapan pengetahuan baru yang didapatkan oleh kelompok, selama berlangsungnya penyelidikan.

\section{Penafsiran}

Pada saat para siswa menjalankan penelitian, mereka secara individual, berpasangan, dan dalam bentuk kelompok kecil, mereka mengumpulkan banyak sekali informasi dari berbagai sumber berbeda. Secara berkala mereka bertemu dengan anggota kelompok mereka untuk bertukar informasi dan gagasan. Penafsiran atas temuan-temuan yang telah mereka gabung merupakan proses negosiasi antara tiap-tiap pengetahuan pribadi siswa dengan pengetahuan baru yang dihasilkan, dan antara tiap-tiap siswa dengan gagasan dan informasi yang diberikan oleh anggota lain dalam kelompok itu.

\section{Motivasi Intrinsik}

Dengan mengundang siswa untuk menghubungkan masalah-masalah yang akan mereka selidiki berdasarkan keingintahuan, pengetahuan, dan perasaan mereka, investigasi kelompok meningkatkan minat pribadi mereka untuk mencari informasi yang mereka perlukan.

\section{Implementasi Group Investigation}

Slavin (2008: 218) menyebutkan dalam Group Investigation, para murid bekerja melalui enam tahap, yaitu :

1. Tahap 1 : Mengidentifikasi topik dan mengatur murid dalam kelompok, meliputi:

a) Para siswa meneliti beberapa sumber, mengusulkan sejumlah topik, dan mengkategorikan saran-saran

b) Para siswa bergabung dengan kelompoknya untuk mempelajari topik yang telah mereka pilih

c) Komposisi kelompok didasarkan pada ketertarikan siswa dan harus bersifat heterogen

d) Guru membantu dalam mengumpulkan infomasi dan memfasilitasi pengaturan

2. Tahap 2: Merencanakan tugas yang akan dipelajari

a) Para siswa merencanakan bersama mengenai:

-) Apa yang kita pelajari ?

-) Bagaimana kita mempelajari ?

-) Siapa melakukan apa (pembagian tugas)?

-) Untuk tujuan atau kepentingan apa kita menginvestigasi topik ini ?

3. Tahap 3: Melaksanakan investigasi

a) Para siswa mengumpulkan informasi, menganalisis data, dan membuat kesimpulan

b) Tiap anggota kelompok berkontribusi untuk usaha-usaha yang dilakukan kelompoknya 
c) Para siswa saling bertukar, berdiskusi, mengklarifikasi, dan menyintesis semua gagasan

4. Tahap 4: Menyiapkan Laporan Akhir

a) Anggota kelompok menentukan pesanpesan esensial dari proyek mereka

b) Anggota kelompok merencanakan apa yang akan mereka laporkan dan bagaimana mereka akan membuat presentasi mereka

c) Wakil-wakil kelompok membentuk sebuah panitia acara untuk mengoordinasikan rencana-rencana presentasi

5. Tahap 5: Mempresentasikan Laporan Akhir

a) Presentasi yang dibuat untuk seluruh kelas dalam berbagai macam bentuk

b) Bagian presentasi tersebut harus dapat melibatkan pendengarnya secara aktif

c) Para pendengar mengevaluasi kejelasan dan penampilan presentasi berdasarkan kriteria yang telah ditentukan sebelumnya oleh seluruh anggota kelas

6. Tahap 6: Evaluasi

a) Para siswa saling memberikan umpan balik mengenai topik tersebut, mengenai tugas yang telah mereka kerjakan, mengenai keefektifan pengalaman-pengalaman mereka

b) Guru dan murid berkolaborasi dalam mengevaluasi pembelajaran siswa

c) Penilaian atas pembelajaran harus mengevaluasi pemikiran paling tinggi
Kelebihan dan Kelemahan Metode Pembelajaran Group Investigation

Dalam penerapan metode Group Investigation terdapat kelemahan dan Kelebihan, adapun kelemahan dan kelebihannya 13yaitu :

1. Kelebihan Metode Pembelajaran Group Investigation

a) Model pembelajaran Group Investigation memiliki dampak positif dalam meningkatkan prestasi belajar siswa

b) Penerapan model ini mempunyai pengaruh positif, yaitu dapat meningkatkan motivasi belajar siswa

c) Pembelajaran yang dilakukan membuat suasana saling bekerjasama dan berinteraksi antar siswa dalam kelompok tanpa memandang latar belakang

d) Model ini juga melatih siswa untuk memiliki kemampuan yang baik dalam berkomunikasi dan mengemukakan pendapat

e) Memotivasi dan mendorong siswa agar aktif dalam proses belajar mulai dari tahap pertama sampai tahap akhir pembelajaran

2. Kelemahan Metode Pembelajaran Group Investigation

a) Model pembelajaran Group Investigation merupakan model pembelajaran yang kompleks dan sulit untuk dilaksanakan dalam pembelajaran kooperatif

b) Model ini membutuhkan waktu yang lama 


\section{METODE PENELITIAN}

Metode penelitian ini memuat: Metode penelitian, Variabel yang diselidiki dan Prosedur penelitian. Hal-hal tersebut dipaparkan secara terperinci berikut ini.

\section{Metode penelitian}

Dalam hal ini penulis menggunkan jenis penelitian Kuantitatif yang digunakan untuk mencari hubungan antara dua variabel yang berbeda dengan rumusrumus statistik untuk memperoleh data utama.

\section{Variabel yang diselidiki}

Dalam penelitian tindakan kelas ini variabel-variabel yang akan diselidiki adalah sebagai berikut:

a. Variabel input : Siswa kelas $\mathrm{X}$ Akuntansi-1 SMK ibnu aqil bogor

b. Variabel proses : Metode kooperatif grup investigatiaon

c. Variabel output : Peningkatan interaksi sosial peserta didik

\section{Prosedur Penelitian}

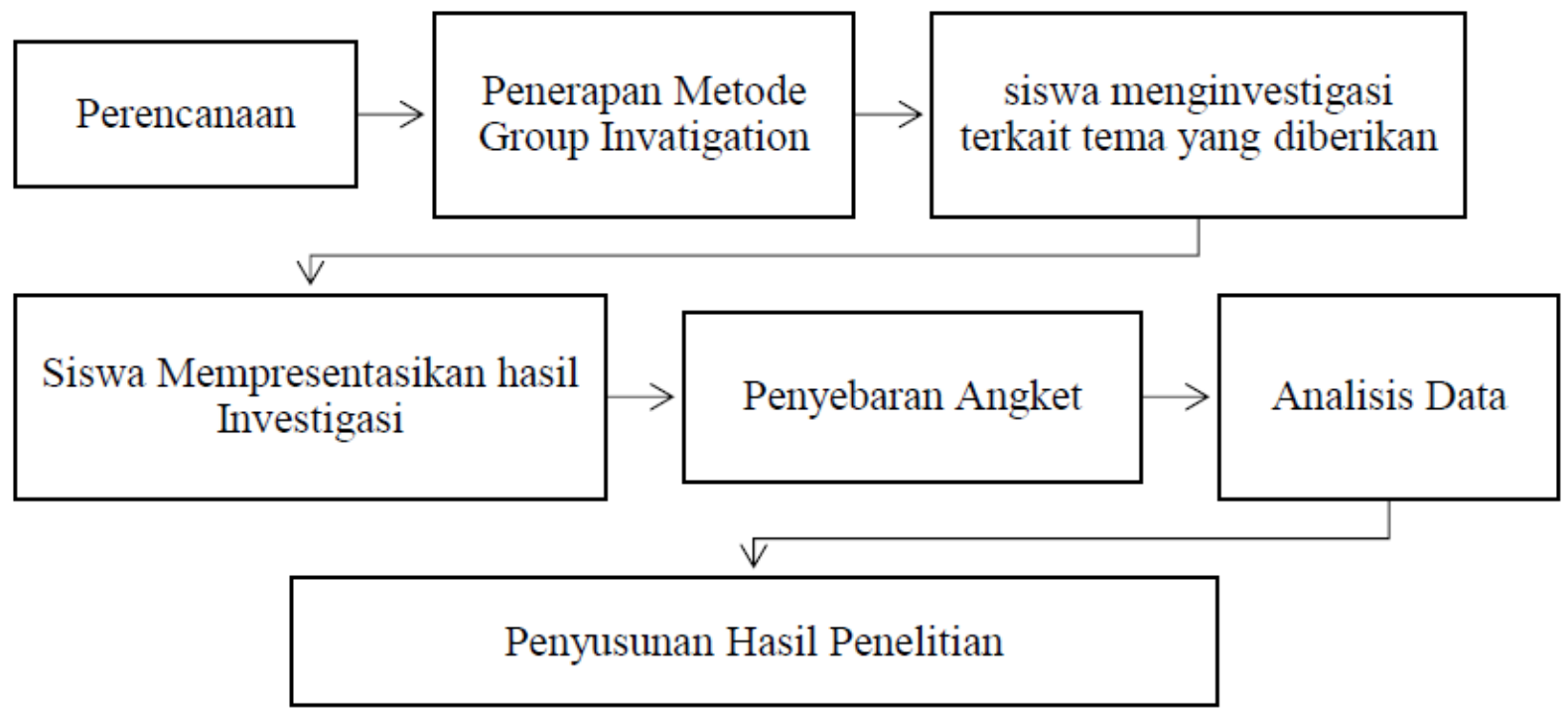

\section{HASIL YANG DI CAPAI}

Setelah MD telah diketahui yaitu 6,3 sedangkan SEMD 0,857 jadi:

$$
\mathrm{T}_{0}=\frac{6,3}{0,857}=7,351
$$

Langkah berikutnya, kita berikan interpretasi terhadap T0, dengan terlebih dahulu memperhitungkan df atau db nya; df $=\mathrm{N}-1=41-1=40$ dengan df sebesar 40 kita konsultasi pada $\pi$ tabel nilai "t", baik taraf signifikansi 5\% maupun pada taraf signifikansi $1 \%$.

Ternyata dengan df sebesar 40 itu diperoleh harga titik $t$ atau ttabel pada signifikansi 5\% sebesar 2,02 sedangkan pada taraf signifikansi $1 \%$ ttabel diperoleh sebesar 2,71.

Dengan membandingkan besarnya "t" yang tercantum pada tabel nilai " $t$ " (ttabel pada $\mathrm{t}$ signifikansi $5 \%=2,02$ dan ttabel pada tsignifikansi $1 \%=2,71$ ) maka dapat kita ketahui bahwa t0 adalah lebih besar dari ttabel, yaitu : 2,02 $<$ 7,351 > 2,71 .

Kesimpulannya; adanya perbedaan interaksi sosial yang signifikan dikalangan 
SMK, antara sebelum dan sesudah di terapkannya metode Group Investigasi.

\section{Potensi Khusus}

Hasil dari penelitian ini dapat digunakan oleh pendidik sebagai pedoman untuk meningkatkan interaksi sosial peserta didik serta untuk meningkatkan kualitas pembelajaran dengan menggunakan metode pembelajaran kooperatif.

\section{PENUTUP}

1) Hasil Pengukuran interaksi siswa dengan menggunakan angket

\begin{tabular}{|c|c|c|c|}
\hline \multirow[b]{2}{*}{ No. } & \multirow[b]{2}{*}{ Nama Siswa } & \multicolumn{2}{|c|}{ Skor Hasil } \\
\hline & & $\begin{array}{c}\text { Sebelum } \\
\text { Penerapan } \\
\text { Metode GI }\end{array}$ & $\begin{array}{c}\text { Setelah Penerapan } \\
\text { Metode GI }\end{array}$ \\
\hline 1. & Adilla Amelia Putri & 68 & 83 \\
\hline 2. & Ahmad Alamul Huda & 69 & 77 \\
\hline 3. & Ahmad Khotibul Umam & 72 & 81 \\
\hline 4. & Alfhiyah Qoirun Nissa & 63 & 78 \\
\hline 5. & Aliyyah Deeandra P & 79 & 85 \\
\hline 6. & Amanda Pratiwi & 76 & 86 \\
\hline 7. & Anisa Aprilia & 80 & 86 \\
\hline 8. & Devi Eprilia & 77 & 73 \\
\hline 9. & Dhea Yashinta Plara & 72 & 71 \\
\hline 10. & Eziza Rahmi & 77 & 85 \\
\hline 11. & Fina Safitri & 74 & 80 \\
\hline 12. & Irna Nur Aulia & 76 & 83 \\
\hline 13. & Lisa Aryani & 77 & 82 \\
\hline 14. & M. Alwi Z & 70 & 81 \\
\hline 15. & M. Fikri D & 72 & 81 \\
\hline 16. & M. Hikmal A & 63 & 77 \\
\hline 17. & M. Ridho R & 78 & 71 \\
\hline 18. & M. Wahyudin & 77 & 86 \\
\hline 19. & Maulana Yusup & 77 & 89 \\
\hline 20. & Meri Lestari & 79 & 77 \\
\hline 21. & Muhammad Alfi Agustin & 65 & 78 \\
\hline 22. & Muhammad Rafindo & 72 & 80 \\
\hline 23. & Muhammad Yuda & 69 & 72 \\
\hline 24. & Mukti Fajrul Alim & 75 & 78 \\
\hline 25. & Pujawati & 64 & 77 \\
\hline 26. & Puspa Nurmala & 81 & 86 \\
\hline 27. & Putri K & 75 & 85 \\
\hline 28. & Rahma Alia & 73 & 76 \\
\hline
\end{tabular}




\begin{tabular}{|l|l|l|l|}
\hline 29. & Ravitha A & 75 & 83 \\
\hline 30. & Rizka Fitria Salsabila & 73 & 78 \\
\hline 31. & Shena Setia Bakti & 79 & 79 \\
\hline 32. & Silvia Rachmawati & 71 & 78 \\
\hline 33. & Siti Mulyani & 71 & 78 \\
\hline 34. & Siti Nur Anjani & 73 & 79 \\
\hline 35. & Siti Nuraeni & 72 & 82 \\
\hline 36. & Siti Nurjanah & 71 & 82 \\
\hline 37. & Suci Indah L & 72 & 75 \\
\hline 38. & Sulastri & 73 & 75 \\
\hline 39. & Veronica Ramanda Putri & 78 & 70 \\
\hline 40. & Viira Verlita L & 76 & 80 \\
\hline 41 & vita verlina Liviany & 74 & 83 \\
\hline
\end{tabular}

2) Hasil perhitungan presentase skor yang Skor yang diperoleh $=85$

Skor maksimum $=5(5 \times 20($ Butir Soal $)=100$

Presentase $=\underline{85} \times 100 \%=85 \%$ 100

Interpretasi data presentase yang diperoleh yaitu "Berdasarkan hasil analisis data, diperoleh presentase skor sebesar $85 \%$. Dengan demikian, dapat kita ketahui kegiatan pembelajaran dari mulai pembukaan sampai penutup dapat dikatakan telah berjalan dengan Baik."

3) Setelah MD telah diketahui yaitu 6,3 sedangkan SEMD 0,857 jadi:

$$
\mathrm{T}_{0}=\frac{6,3}{0,857}=7,351
$$

Langkah berikutnya, kita berikan interpretasi terhadap T0, dengan terlebih dahulu memperhitungkan df atau db nya; $\mathrm{df}=\mathrm{N}-1=41-1=40$ dengan df sebesar 40 kita konsultasi pada $\pi$ tabel nilai “ $t$ ", baik taraf signifikansi 5\% maupun pada taraf signifikansi $1 \%$.

Ternyata dengan df sebesar 40 itu diperoleh harga titik $\mathrm{t}$ atau ttabel pada signifikansi 5\% sebesar 2,02 sedangkan pada taraf signifikansi $1 \%$ ttabel diperoleh sebesar 2,71.

Dengan membandingkan besarnya " $\mathrm{t}$ " yang tercantum pada tabel nilai " $\mathrm{t}$ " (ttabel pada $\mathrm{t}$ signifikansi 5\% = 2,02 dan ttabel pada tsignifikansi $1 \%=2,71$ ) maka dapat kita ketahui bahwa t0 adalah lebih besar dari ttabel, yaitu : 2,02 < 7,351 > 2,71 .

\section{Saran}

Adapun saran-saran yang peneliti sampaikan adalah sebagai berikut:

1) Guru dapat menerapkan model GI (Group Investigation) dalam pembelajaran yang memerlukan analisis, sehingga siswa dapat mengetahui sisi ideal dan sisi kenyataan yang ada dalam menghadapi suatu problema.

2) Karna memerlukan waktu yang sedikit panjang, maka dalam penerapan metode ini guru harus sudah merancang langkah demi langkahnya secara matang.

3) Diharapkan bagi setiap guru untuk menerapkan metode - metode pembelajaran kooperatif dalam setiap pembelajaran demi tercapaimya tujuan 
pembelajaran yang telah dirumuskan sebelumnya

\section{DAFTAR PUSTAKA}

Rusman, (2011). Model-Model Pembelajaran: Mengembangkan Profesionalisme Guru. Rajawali Pers. Jakarta

Slavin, Robert E. (2005). Cooperative Learning Teori, Riset dan Praktik. Penerbit Nusa Media. Bandung

Taniredja,Tukiran. dkk. (2011). ModelModel Pembelajaran Inovatif. Alfabeta. Bandung

Kurniasih Imas \& Berlin Sani. (2016). Ragam Pengembangan Model Pembelajaran Untuk Meningkatkan Profesionalitas Guru. Penerbit Kata Pena

Jacobsen, David A. dkk. (2009). Methods For Teaching Metode-metode Pengajaran Meningkatkan Belajar Siswa TK-SMP. Pustaka Pelajar. Yogyakarta
Isjoni (2014). Cooperative Learnung Mengembangkan Kemampuan Belajar Berkelompok. Alfabeta. Bandung

Soekanto, Soerjono dan Budi Sulistyowati. (2017). Sosiologi Suatu Pengantar. PT Raja Grafindo. Jakarta

Syani, Abdul. (2002). Sosiolagi dan SkematikaTeori dan Terapan. PT Bumi Aksara. Jakarta

Herimanto dan Winarno. (2012). Ilmu Sosial dan Budaya Dasar. Edisi kesatu, Cetakan kelima. PT Bumi Aksara. Jakarta

Soekanto, Soerjono. (2005). Sosiologi Suatu Pengantar. PT RajaGrafindo Persada. Jakarta

Sunarto, Kamanto. (2000). Pengantar Sosiologi. Edisi kedua. Lembaga Penerbit Fakultas Ekonomi Universitas Indonesia. Jakarta 